\title{
Pengaruh Harga dan Pelayanan terhadap Keputusan Pembelian Konsumen pada Online Shop
}

\author{
Sudirman
}

UIN Alauddin Makassar

yudih65@yahoo.co.id

\begin{abstract}
This study aims to determine the effect of prices and services on consumer decisions in an online shop. Study on Islamic Economics and Business Faculty IAIN Sultan Amai Gorontalo Students. The sample selection method is done by using accidental sampling method. The number of samples chosen was 100 students. Data obtained through the distribution of questionnaires to the respondent. Data analysis was performed using multiple regression analysis tools. The type of data used is perimer data. The method of data collection is done by distributing questionnaires to those who are randomly responded. Data analysis was carried out using multiple regression analysis. The result of this study find out that the prices and services of online transactions together and partially positive and significant towards consumer decisions in conducting online purchase and purchase transactions at the Faculty of Economics and Islamic Business Sultan Amai Gorontalo IAIN, namely price variables with an exchange rate of 0.356 with a significant 0.034. Service variable with a coefficient of 2.423 with a significant value of 0.010. Then, together prices and services have a positive and significant effect on consumer decisions with the calculated $F$ value $=5.930$ significance 0.004 greater than $F$ table $=3.590$.
\end{abstract}

Keywords: Price, Service, Decision making

\section{A. PENDAHULUAN}

Di era globalisasi yang sedang berlangsung saat ini telah diwarnai oleh perkembangan teknologi yang sangat pesat. Situasi tersebut berdampak luas terhadap kehidupan masyarakat. Perkembangan teknologi telah banyak mengubah pola perilaku masyarakat dalam berbagai aspek kehidupannya. Kemajuan teknologi, telah merambat ke dalam dunia bisnis. Karena itu, perkembangan teknologi informasi telah banyak merubah pola perilaku masyarakat dalam menjalankan aktivitas kesehariannya, termasuk dalam hal melakukan transaksi jual beli. Dulu, transaksi niaga hanya dapat dilakukan dengan menghadirkan kedua belah pihak yang bertransaksi dalam satu majelis. Saat ini, dengan adanya jaringan internet, maka jarak tidak lagi menjadi kendala untuk bertransaksi. Transaksi seperti itu populer disebut jual beli online. Transaksi dengan jaringan internet bukan hanya untuk transaksi jual beli barang dan jasa, tetapi juga transaksi penukaran mata uang, penarikan uang tunai, dan pengiriman uang serta berbagai 
transaksi lainnya. Para pelaku bisnis telah memanfaatkan kemajuan teknologi informatika untuk melayani para nasabahnya. Saat ini, transaksi online sudah menjadi trend baru dalam dunia perkembangan bisnis. Fenomena tersebut, terus berkembang di kalangan masyarakat.

Jual beli online merupakan dampak konkret perkembangan teknologi terhadap dunia bisnis. Saat ini, terdapat kecenderungan masyarakat untuk bergeser dari transaksi ofline ke transaksi online. Dulu, transaksi jual beli hanya bisa dilakukan dengan secara langsung bertatap muka antara penjual dan pembeli. Namun, seiring dengan pesatnya perkembangan teknologi informasi dewasa ini, telah banyak merubah pola perilaku masyarakat untuk beralih ke sistem jual beli online. Oleh karena itu, penggunaan jasa layanan internet telah mengambil porsi yang lebih besar dalam kehidupan masyarakat. Saat ini internet telah menjadi bagian dari gaya hidup atau pun kebutuhan hidup.

Dalam perkembangannya, internet sekarang bukan hanya berfungsi sebagai media informasi dan media komunikasi saja. Namun lebih dari itu, saat ini fasilitas internet juga telah dijadikan sebagai media untuk mendukung aktivitas perdagangan. Sekarang sudah banyak orang yang memanfaatkan internet sebagai media pemasaran dan bisnis. Seperti Lazada, Toko Bagus, Traveloka, dan masih banyak lagi yang lainnya. Semakin berkembangya jumlah Online shop membuat masyarakat memiliki banyak pilihan untuk melakukan transaksi, tentu dengan memperhatikan harga maupun kualitas yang ditawarkan oleh mereka.

Online shop merupakan suatu aktivitas jual beli produk atau jasa yang ditawarkan melalui internet. Online Shopping merupakan suatu bentuk perdagangan elektronik yang sedang marak. Terdapat beberapa alasan yang melatarbelakangi sistem jual beli online menjadi pilihan oleh sebahagian kalangan masyarakat di Indonesia, termasuk di Gorontalo adalah selain waktunya fleksibel juga kecenderungan menawarkan barang dengan harga yang lebih murah daripada di toko fisik. Karena pemilik toko online biasanya tidak perlu menyediakan toko fisik sehingga mereka mampu menghemat biaya operasional dan biaya lainnya, sehingga toko online bisa menjual barang dengan harga yang lebih murah daripada di toko fisik. Bahkan juga menyediakan barang secara grosir sehingga harga jauh lebih murah dari pada harga satuan. Beberapa online shop juga menawarkan ongkos kirim gratis dan discount khusus pada situasi tertentu. Ini menjadi daya tarik tersendiri bagi masyarakat, sehingga membuat mereka memilih untuk membeli barang yang dibutuhkan secara online. Salah satu kelebihan dari transaksi online adalah harga barangnya relatif lebih murah daripada belanja langsung di toko. 
Harga merupakan faktor penentu yang mempengaruhi pembelian. Suatu produk akan mudah diterima konsumen ketika harga produk tersebut bisa dijangkau oleh kosumen. Menurut Tripjono (2015: 42) harga merupakan suatu nilai yang harus dikorbankan oleh konsumen untuk mendapatkan produk atau jasa dari produsen. Sementara dalam sudut pandang konsumen, harga seringkali digunakan sebagai indikator nilai bagaimana harga tersebut dihubungkan dengan manfaat yang dirasakan atas suatu barang atau jasa. Dengan demikian, agar dapat sukses dalam memasarkan suatu barang atau jasa, setiap perusahaan harus mampu menetapkan harganya secara tepat.

Selain harga, kualitas layanannya juga cukup baik, karena selain murah, juga praktis, cepat, dan mudah. Kelebihan dari transaksi online adalah bisa dilakukan kapan saja dan dimana saja. Karena itu, proses berbelanja online memiliki dampak positif terhadap kualitas pelayanan. Menurut Zeithalm dan Bitner (2009: 40), kualitas pelayanan adalah tingkat keunggulan yang diharapkan dan pengendalian atas tingkat keunggulan tersebut untuk memenuhi keinginan pelanggan. Menurut Wyckof dalam Fandi Tripjono (2003: 331) bahwa kualitas jasa merupakan keunggulan (exellence) yang diharapkan dan pengendalian atas keunggulan tersebut untuk memenuhi keunggulan pelanggan.

Keputusan pembelian adalah proses yang digunakan untuk memilih suatu tindakan sebagai cara pemecahan masalah. Dari definisi di atas, dapat disimpulkan bahwa pengambilan keputusan itu adalah suatu cara yang digunakan untuk memberikan suatu pendapat yang dapat dalam menyelesaikan suatu masalah dengan cara atau teknik tertentu agar keputusan tersebut dapat lebih diterima oleh semua pihak (Ismail, 2019). Fasilitas transaksi online, menjadi salah satu cara atau teknik yang dirancang unttuk dapat memecahkan masalah oleh penjual dan pembeli untuk bertransaksi. Inilah yang menjadi salah satu daya tarik oleh para konsumen untuk berbelanja secara online.

Online shop kini semakin marak dan dipercaya dikalangan mahasiswa termasuk mahasiswa Fakultas Ekonomi dan Bisnis Islam (FEBI) IAIN Sultan Amai Gorontalo. Dari hasil observasi maupun wawancara yang telah dilakukan secara langsung kepada mahasiswa FEBI IAIN Sultan Amai Gorontalo, ditemukan kebanyakan dari mereka beranggapan bahwa berbelanja secara online lebih praktis, karena tanpa harus pergi ke toko-toko, pemesanan barang bisa dilakukan kapanpun dan dimanapun, menghemat biaya dan tenaga, serta harga yang ditawarkan jauh lebih murah dari harga toko. Dari beberapa kemudahan tersebut, menjadi alasan yang kuat 
mendorong mereka beralih dengan berbelanja online. Berbelanja online bisa dilakukan dengan menggunakan smartphone. Jadi, smartphone bukan hanya sebagai fasilitas telekomunikasi saja, akan tetapi juga sebagai media untuk berbelanja melalui online. Saat ini jumlah mahasiswa yang melakukan transaksi secara online pada Fakultas Ekonomi dan Bisnis Islam IAIN Sultan Amai Gorontalo terus meningkat. Berdasarkan hasil survey awal yang telah dilakukan terdapat 96 orang jumlah mahasiswa yang telah melakukan belanja online, dan kebanyakan dari mereka menyatakan puas. Berdasarkan uraian tersebut, maka penulis tertarik untuk melakukan penelitian dengan berjudul, "Pengaruh Harga dan Pelayanan terhadap Keputusan Konsumen dalam Melakukan Transaksi Jual Beli Online di Kalangan Mahasiswa Fakultas Ekonomi dan Bisnis Islam (FEBI) IAIN Sultan Amai Gorontalo."

\section{B. KAJIAN TEORI}

Perilaku konsumen merupakan suatu proses yang berkaitan erat dengan proses pembelian. Pada saat itu konsumen melakukan aktivitas-aktivitas seperti pencarian, penelitian, dan pengevaluasian produk. Perilaku konsumen merupakan hal-hal yang mendasari konsumen untuk membuat keputusan pembelian.

Menurut Philip Kotler dan Amstrong dalam Nembah F. (2008: 179), proses keputusan pembelian merupakan suatu perilaku konsumen untuk menentukan suatu proses pengembangan keputusan dalam membeli suatu produk. Proses tersebut merupakan sebuah penyelesaian masalah harga yang terdiri dari lima tahap. Berikut lima tahap proses keputusan pembelian yaitu pengenalan masalah, penerimaan informasi, penilaian pilihan, keputusan pembelian dan perilaku pasca beli.

Harga merupakan salah satu faktor yang penting dalam mempertahankan dan memenangkan persaingan. Harga merupakan jumlah nilai yang harus dikorbankan untuk mendapatkan produk dari konsumen. Oleh karena itu, agar dapat sukses dalam memasarkan suatu barang atau jasa oleh setiap perusahaan, maka harus mampu menetapkan harga yang tepat. Sementara dalam sudut pandang konsumen, harga seringkali digunakan sebagai indikator nilai dari sebuah produk, bagaimana harga tersebut dihubungkan dengan manfaat yang dirasakan atas suatu barang atau jasa. Menurut Philip Kotler (2010: 314) harga adalah sejumlah uang yang dibebankan untuk sebuah produk atau jasa/layanan. Dengan kata lain, harga adalah keseluruhan 
nilai yang ditukarkan konsumen untuk mendapatkan keuntungan dari kepemilikan terhadap sebuah produk atau jasa.

Fungsi harga dalam membantu para pembeli untuk memutuskan cara memperoleh manfaat atau utilitas tertinggi yang diharapkan oleh setiap konsumen dengan berdasarkan daya belinya. Dengan demikian, penetapan harga dapat membantu para pembeli untuk memutuskan cara mengalokasikan daya belinya pada berbagai jenis barang dan jasa. Pembeli membandingkan harga dari berbagai alternatif yang tersedia, kemudian memutuskan alokasi dana yang dikehendaki. Indikator yang mencirikan harga yang digunakan dalam penelitian ini, yaitu keterjangkauan harga, kesesuaian harga dengan kualitas produk, daya saing harga, kesesuaian harga dengan manfaat, potongan harga (discount) (Kotler, 2001: 339-340).

Selain harga, pelayanan juga adalah merupakan faktor penting dalam memenuhi kepuasan konsumen. Pelayanan adalah suatu keadaan dinamis yang berkaitan erat dengan produk, jasa, sumber daya manusia, serta proses dan lingkungan yang dapat memberikan kepuasan kepada setiap konsumen. Menurut Tripjono, definisi kualitas pelayanan ini adalah upaya pemenuhan kebutuhan yang dibarengi dengan keinginan konsumen serta ketetapan cara penyampaiannya agar dapat memenuhi harapan sebagai penentu terhadap ukuran kepuasan pelanggan tersebut.

Menurut Parasuran, Zeitaml dan Beri (1998) dalam bukunya Tjiptono, terdapat lima dimensi yang digunakan untuk mengevaluasi kualitas pelanggan, yaitu pertama, Bukti Langsung (Tangibles), berkenaan dengan penanmpilan fisik fasilitas layanan, peralatan, perlengkapan, sumber daya manusia dan materi komunikasi; kedua, kehandalan (Reliability), kemampuan perusahaan untuk menyampaikan layanan yang disajikan secara akurat; ketiga, Daya Tanggap (Responsiveness), berkenaan dengan kesediaan dan kemampuan penyedia layanan untuk membantu para pelanggan dan merespon permintaan mereka dengan cepat; keempat Jaminan (Assurance), berkenaan dengan pengetahuan dan kesopanan karyawan serta kemampuan mereka menumbuhkan rasa percaya dan keyakinan pelanggan; dan kelima, Empati (Empathy), ada upaya untuk memahami masalah para pelanggan dan bertindak demi kepentingan pelangan, serta memberikan perhatian personal kepada para pelanggan dan memiliki jam operasi yang nyaman.

Kualitas pelayanan adalah tingkat pelayanan yang diberikan oleh manajemen untuk memenuhi harapan pengunjung (Tjiptono, 2008: 97). Kualitas adalah keseluruhan ciri serta sifat suatu produk atau jasa yang berpengaruh pada kemampuannya untuk memuaskan kebutuhan 
yang dinyatakan atau yang tersirat. Dengan semakin ketatnya persaingan antar perusahaan, suatu perusahaan harus terus berinovasi dalam menjalankan strategis bisnisnya.

\section{METODE PENELITIAN}

Penelitian ini mengunakan desain penelitian eksplanatif (komfirmatif). Desain ini dimaksudkan untuk melakukan proses mengkomfirmasi terhadap pengaruh variabel bebas dengan variabel terikatnya. Hal ini sejalan dengan yang dikemukakan oleh Zikmund (1994: 68) bahwa causal research yang dirancang untuk mengidentifikasi causa and effect relationships antar variabel dimana masalah penelitian telah didefenisikan dengan jelas.

Populasi penelitian adalah seluruh mahasiswa pada Fakultas Ekonomi dan Bisnis Islam (FEBI) IAIN Sultan Amai Gorontalo yang telah melakukan pembelian melalui transaksi online. Namun, karena peneliti sulit untuk menetukan secara pasti jumlah mahasiswa yang telah melakukan transaksi secara online, maka metode penetuan jumlah sampel dilakukan secara accindental (Arifin, 2010: 215). Penelitian ini mengambil sampel sebesar 100 orang mahasiswa. Data yang terkumpul kemudian dianalisis menggunakan aplikasi SPSS 24.

Penelitian ini menggunakan data perimer yang dikumpulkan langsung dari responden melalui pengisian kuisioner. Data dianalisis dengan menggunakan analisis kuantitatif dengan menggunakan alat analisis statistik, yaitu dengan model regresi linear berganda yang dinyatakan dalam bentuk fungsi sebagai berikut:

$$
Y=\beta_{0}+\beta_{1} X_{1}+\beta_{2} X_{2}+e_{i}
$$

Dimana:

$$
\begin{aligned}
& \beta_{0}=\text { konstanta } \\
& \beta_{1} \text { dan } \beta_{2} \text { adalah koefisien regresi } \\
& e_{i}=\text { error term (Tingkat kesalahan) } \\
& Y=\text { Keputusan pembelian } \\
& X_{1}=\text { Harga } \\
& X_{2}=\text { Layanan transaksi online }
\end{aligned}
$$

Pengujian Hipotesis dilakukan dengan menggunakan uji t dan uji F. Adapun penjelasan dari masing-masing uji tersebut adalah sebagai berikut: 


\section{a. Uji t}

Untuk melihat hubungan variabel bebas terhadap variabel terikat dengan secara parsial, berdasarkan hasil model dalam regresi, maka dilakukan pegujian hipotesis yaitu uji parsial (uji t).Pengujian hipotesis yang digunakan sebagai berikut:

Ho = 0 (Berarti tidak terdapat pengaruh antara variabel independen terhadap variabel dependen).

$\mathrm{H}_{1} \neq 0$ (Berarti terdapat pengaruh antara variabel independen terhadap dependen).

Jika $\mathrm{t}$ hit $>\mathrm{t}$ tabel maka $\mathrm{H}_{0}$ ditolak, Jika $\mathrm{t}$ hit $<\mathrm{t}$ tabel maka $\mathrm{H}_{0}$ diterima

b. uji F

Untuk membuktikan kebenaran hipotesis sembilan digunakan uji F, yaitu untuk menguji keberartian regresi secara keseluruhan. Pengujian melalui uji $\mathrm{F}$ atau variasinya adalah dengan menggunakan analisis regresi dengan membandingkan Prob Fh ( $\mathrm{F}$ hitung variabel) dengan taraf signifikansi yang digunakan, yaitu 0,05. Apabila hasil perhitungan menunjukkan: Fh Prob < 0,05 (Ho ditolak, Ha diterima). Artinya variasi dari model regresi dapat menjeskan bahwa variabel bebas secara bersama-sama pengaruhnya terhadap variabel tidak bebasnya. Apabila Fh Prob > 0,05 (Ho diterima, Ha ditolak). Artinya variasi dari model regresi tidak dapat menjelaskan pengaruh variabel bebas terhadap variabel tidak bebasnya.

Selanjutnya untuk melihat kemampuan variabel bebas dalam menjelaskan variabel tidak bebasnya dapat diketahui dari besarnya koefisien determinasi berganda $\left(\mathrm{R}_{2}\right)$. Hal ini dapat diartikan nilai koefisien determinasi berganda digunakan untuk mengukur besarnya sumbangan dari variabel tidak bebasnya. Jika $\mathrm{R}_{2}$ yang diperoleh dari hasil perhitungan semakin besar atau mendekati satu, maka dapat dikatakan bahwa sumbangan terhadap variasi variabel tidak bebasnya semakin besar. Hal ini berarti model yang digunakan semakin kuat untuk menerangkan variasi variabel tidak bebasnya.

Sebaliknya jika $\mathrm{R}_{2}$ semakin kecil atau mendekati nol, maka dapat dikatakan bahwa sumbangan dari variabel bebas terhadap variasi nilai variabel tidak bebasnya semakin kecil. Hal ini berarti model yang digunkan semakin lemah untuk menjelaskan variasi variabel terikat. Secaara umum dapat dikatakan bahwa besarnya koefisien determinasi berganda (R2) berada diantara 0 dan 1 atau $0<\mathrm{R} 2<1$. 


\section{Pembahasan}

Untuk mengetahui dan menganalisis pengaruh perubahan harga $\left(\mathrm{X}_{1}\right)$, layanan transaksi online $\left(\mathrm{X}_{2}\right)$ terhadap Keputusan pembelian $(\mathrm{Y})$, maka dilakukan analisis statistik yaitu analisis regresi berganda dengan menggunakan data primer yang diperoleh langsung dari responden melalui pengisian kuisioner. Nilai koefisien regresi pada setiap variable independen, nilai R, nilai $\mathrm{R}_{2}$ serta nilai, dan nilai adjust serta nilai f hitung dan $\mathrm{t}$ hitung dapat dilihat pada tabel berikut:

Tabel 1. Statitik Deskriptif

\begin{tabular}{ccccc}
\hline Variabel & Koefisien $\boldsymbol{\beta}$ & $\begin{array}{c}\text { Standar } \\
\text { Eror }\end{array}$ & $\begin{array}{c}\text { Nilai t } \\
\text { hitung }\end{array}$ & Sig \\
\hline Constan & 10,770 & 2,270 & 9,514 & $\left.0,000^{* *}\right)$ \\
\hline $\mathbf{X 1}$ & $-1,024$ & 0.104 & 2,009 & $\left.0,018^{*}\right)$ \\
\hline $\mathbf{X 2}$ & 0,356 & 0,126 & 2,623 & $\left.0,010^{*}\right)$ \\
$\mathbf{R = \mathbf { 0 . 7 5 1 }}$ & $\mathbf{R}^{\mathbf{2}=\mathbf{0 , 7 2 0}}$ & $\mathbf{R}$ adjust $=\mathbf{0 , 7 0 4}$ & $\mathbf{N}=\mathbf{1 0 0}$ & $\mathbf{k}=\mathbf{3}$ \\
$\mathbf{F}$ hitung $=\mathbf{1 3 , 1 3 0}$ & $\mathbf{S i g}=\mathbf{0 , 0 0 0}$ & & & \\
\end{tabular}

Hasil estimasi analisis regresi pada setiap variabel, terdapat beberapa keputusan yang dapat diambil, yaitu Pertama, nilai $\mathrm{R}=0.750$ adalah nilai koefisien korelasi, nilai ini berarti hubungan antara variabel independen, yaitu: Harga $\left(X_{1}\right)$, Pelayanan $\left(X_{2}\right)$, terhadap variabel dependen yaitu Keputusan Konsumen (Y) adalah cukup kuat. Nilai $\mathrm{R}^{2}=0,72$ adalah koefisien determinasi. Nilai ini berarti variasi variabel independen yang dapat menjelaskan variabel dependen sebesar 72 persen dan sisanya hanya 28 persen dipengaruhi oleh variabel lain yang tidak dijelaskan dalam model. Dengan demikian, model ini sudah cukup layak.

Kedua, uji F digunakan untuk menguji pengaruh secara simultan variabel independen terhadap variabel dependen. Dari hasil estimasi diperoleh F hitung $=13,130$ dengan signifikansi 0,000, maka ini berarti $\mathrm{F}$ hitung lebih besar dari $\mathrm{F}$ tabel = 3,090 dengan tingkat signifikan 5\%, sehingga Ho ditolak dan $\mathrm{H}_{1}$ diterima, dengan demikian secara simultan terdapat pengaruh yang signifikan antara Harga $\left(\mathrm{X}_{1}\right)$, Pelayanan $\left(\mathrm{X}_{2}\right)$, terhadap variabel dependen yaitu Keputusan pembelian Konsumen (Y). 
Ketiga, Uji t digunakan untuk menguji secara parsial pengaruh variabel independen terhadap variabel dependen. Dari hasil estimasi diperoleh nilai konstanta sebesar 15,983 . Nilai ini berarti, jika Harga $\left(\mathrm{X}_{1}\right)$ dan Pelayanan $\left(\mathrm{X}_{2}\right)$ konstan, maka nilai Keputusan Konsumen (Y) sebesar 2,273 poin.

Pada penelitian ini, ditemukan bahwa Harga $\left(\mathrm{X}_{1}\right)$ berpengaruh negatif dan signifikan terhadap keputusan pembelian Konsumen (Y) untuk melakukan pembelian pada online shop. Dari hasil estimasi, diperoleh nilai koefisien regresi Harga $\left(\mathrm{X}_{1}\right)$ sebesar -1,240. Nilai ini berarti jika Harga $\left(\mathrm{X}_{1}\right)$ ditingkatkan/diturunkan sebesar 1 satuan, maka nilai Keputusan Konsumen (Y) akan meningkat/menurun pula sebesar 0,240 satuan, dengan asumsi variabel independen lain konstant. Dan nilai t hitung $=2,009$ dan signifikansi $=0,018$, maka ini berarti $\mathrm{t}$ hitung lebih besar dari t tabel 1,980 dengan tingkat signifikan 5\%. Maka Ho ditolak dan $\mathrm{H}_{1}$ diterima. Dengan demikian, terdapat pengaruh yang signifikan antara variabel $\mathrm{X}_{1}$ terhadap $\mathrm{Y}$.

Hasil penelitian ini menunjukkan bahwa harga berpengaruh negatif dan signifikan terhadap keputusan pembelian Mahasiswa Fakultas Ekonomi dan Bisnis Islam IAIN Sulatan Amai Gorontalo pada online shop. Dengan demikian, apabila harga diturunkan maka mahasiswa akan meningkatkan transaksi pembelianya. Begitu pula sebaliknya, jika harga cenderung meningkat, maka konsumen akan mengurangi permintaanya. Hasil penelitian ini sejalan dengan teori Harga yang dikembangkan oleh Kotler dan Keller.

Harga merupakan hal yang cukup diperhatikan oleh setiap konsumen dalam proses pengambilan keputusan pembelian produk dan jasa. Harga adalah merupakan persepsi nilai oleh pembeli terhadap suatu produk. Karena itu, biasanya oleh konsumen selalu melakukan proses identifikasi dengan nilai produk. Apakah produk tersebut ditawarkan dengan harga yang sesuai atau tidak. Apabila konsumen menganggap biaya yang dikeluarkan lebih besar daripada nilai manfaat yang diterima pada setiap membeli suatu barang, maka produk tersebut tersebut bernilai negatif, dan diasumsikan mahal. Nilai tersebut dianggapnya sebagai nilai yang buruk, karena itu ada kemungkinan konsumen mengurangi konsumsinya, atau bahkan memutuskan untuk tidak mengkonsumsi produk tersebut. Sebaliknya, jika manfaat yang diterima lebih besar, maka produk tersebut bernilai positif (Lupiyadi \& Hamdani).

Harga merupakan salah satu faktor yang cukup penting dalam mempertahankan maupun memenangkan persaingan. Konsumen selalu cenderung tertarik dengan harga yang murah dengan 
kualitas yang baik. Oleh karena itu, harga merupakan faktor penting dalam menyukseskan pemasaran suatu barang atau jasa. Dengan demikian, setiap perusahaan harus dapat menetapkan harga pada suatu produk secara tepat. Sementara dari sudut pandang konsumen harga seringkali digunakan sebagai indikator nilai bagaimana harga tersebut dihubungkan dengan manfaat yang dirasakan atas suatu barang atau jasa. Disamping itu, harga merupakan unsur utama dalam sumber pemasukan atau pendapatan bagi perusahaan.

Fungsi harga dalam membantu para pembeli untuk memutuskan cara memperoleh manfaat atau utilitas tertinggi yang diharapkan oleh setiap konsumen berdasarkan daya belinya. Dengan demikian, adanya harga dapat membantu para pembeli untuk memutuskan cara mengalokasikan daya belinya pada berbagai jenis barang dan jasa. Pembeli membandingkan harga dari berbagai alternatif yang tersedia, kemudian memutuskan alokasi dana yang dikehendaki.

Hasil penelitian ini, sejalan dengan hasil penelitian yang telah dilakukan oleh Dwi Widayati (2012: 8) yang meneliti tentang pengaruh kualitas produk dan harga terhadap keputusan pembelian produk Tupperware oleh masyarakat Yogyakarka. Pada penelitian tersebut, ditemukan bahwa variabel harga berpengaruh positif dan signifikan terhadap keputusan pembelian Tupperware oleh masyarakat Yogyakarta.

Pengaruh layanan sistem transaksi online $\left(\mathrm{X}_{2}\right)$ terhadap Keputusan Konsumen $(\mathrm{Y})$. Dari hasil estimasi diperoleh nilai koefisien regresi Pelayanan $\left(\mathrm{X}_{2}\right)$ sebesar 0,423. Nilai ini berarti, jika Pelayanani $\left(\mathrm{X}_{2}\right)$ ditingkatkan/diturunkan sebesar 1 satuan, maka nilai indeks harga saham (Y) akan meningkat /menurun pula sebesar 0,423 poin, dengan asumsi variabel independen lain konstant. Dan nilai t hitung $=2,893$ dan signifikansi $=0,000$, maka ini berarti t hitung lebih besar dari t tabel 1,980, dengan tingkat signifikan 5\%. Maka Ho ditolak dan $\mathrm{H}_{1}$ diterima. Dengan demikian, terdapat pengaruh yang signifikan antara variabel $\left(\mathrm{X}_{2}\right)$ terhadap $(\mathrm{Y})$.

Pada penelitian ini menunjukkan bahwa pelayanan berpengaruh positif dan signifikan terhadap keputusan pembelian konsumen mahasiswa Fakultas Ekonomi dan Bisnis Islam IAIN Sultan Amai Gorontalo. Apabila kualitas layanan pada sistem jual beli online ditingkatkan, maka akan diikuti pula oleh minat konsumen untuk melakukan transaksi pembelian. Begitu pula sebaliknya, jika kualitas layanan pada system jual beli online menurun, maka akan menurun pula minat konsumen untuk melakukan transaksi. Terdapat beberapa kelebihan dari system belanja online, yakni, berbelanja secara online lebih praktis, karena tanpa harus pergi ke toko-toko, 
pemesanan barang bisa dilakukan kapanpun dan dimanapun, menghemat biaya dan tenaga, serta harga yang ditawarkan jauh lebih murah dari harga toko. Dari beberapa kemudahan tersebut, menjadi alasan yang kuat mendorong mereka beralih dengan berbelanja online. Berbelanja online bisa dilakukan dengan menggunakan smartphone. Jadi smartphone bukan hanya sebagai fasilitas telekomunikasi saja, akan tetapi juga sebagai media untuk berbelanja melalui online. Saat ini jumlah mahasiswa yang melakukan transaksi secara online pada Fakultas Ekonomi dan Bisnis Islam IAIN Sultan Amai Gorontalo terus meningkat. Berdasarkan hasil survey awal yang telah dilakukan terdapat 96 orang jumlah mahasiswa yang telah melakukan belanja online, dan kebanyakan dari mereka menyatakan puas dan akan melakukan pembelian berulang.

Hasil penelitian ini sejalan dengan dengan teori yang dikembangkan oleh Zeithaml, Bitner, dan Gremler (2009). Menurut Zeithaml, konsumen akan cenderung meningkatkan konsumsinya apabila mereka puas terhadap suatu barang dan jasa. Kepuasan adalah merupakan faktor paling penting oleh setiap konsumen dalam memutuskan untuk mengonsumsi suatu barang. Kepuasan sangat ditentukan oleh nilai manfaat dari setiap barang. Semakin tinggi nilai manfaat suatu produk, semakin meningkat pula kepuasan konsumen, begitu pula sebaliknya. Karena itu, permintaan terhadap suatu produk akan cenderung meningkat apabila mampu memenuhi kepuasan konsumen. Selain harga, pelayanan juga merupakan salah satu faktor yang cukup penting yang berpengaruh terhadap kepuasan konsumen. Setiap konsumen selalu ingin mendapatkan barang dengan harga murah serta pelayanan yang baik. Oleh karena itu, produsen sangat penting untuk memahami factor-faktor yang mempengaruhi perilaku dalam pengambilan keputusan konsumen. Berkaitan dengan itu, ada lima dimensi yang digunakan oleh Zeithaml dan Bitner (2009: 42) untuk mengukur kualitas pelayanan, yaitu bukti langsung (Tangible), keandalan (Reliability), daya tanggap (Responsiveness), Jaminan (Assurance), dan Kepedulian (Empaty).

Menurut Zeithaml dan Bitner, kualitas pelayanan adalah tingkat keunggulan yang diharapkan dan pengendalian atas tingkat keunggulan tersebut untuk memenuhi keinginan pelanggan. Menurut Wyckof dalam Fandi Tripjono bahwa kualitas jasa merupakan keunggulan (exellence) yang diharapkan dan pengendalian atas keunggulan tersebut untuk memenuhi keunggulan pelanggan. Karena dianggap praktis, cepat, mudah, kegiatan berbelanja secara online berkembang sangat pesat beriringan dengan semakin banyaknya pengguna internet dikalangan umum (Tjiptono, 2007: 71). 
Penelitian ini sejalan dengan hasil penelitian yang telah dilakukan oleh Amrullah, Pamasang S. Siburian, dan Saida Zainurossalamia (2016) yang meneliti tentang kualitas produk dan kualitas layanan terhadap keputusan pembelian sepeda motor Honda. Pada penelitian tersebut ditemukan bahwa kualitas layanan pada dealer Hondar Star Motor Samarinda berpengaruh positif dan signifikan terhadap keputusan pembelian motor Honda oleh konsumen.

\section{E. SIMPULAN}

Berdasarkan uraian pembahasan hasil penelitian di atas, maka kesimpulan masalah penelitian dapat dirumuskan sebagai berikut: Harga berpengaruh negatif dan signifikan terhadap keputusan konsumen mahasiswa Fakultas Ekonomi dan Bisnis Islam IAIN Sultan Amai Gorontalo untuk melakukan transaksi jual beli online. Pada penelitian ini diperoleh nilai estimasi koefisien regresi variable harga sebesar -1,240. Nilai ini berarti jika Harga $\left(\mathrm{X}_{1}\right)$ ditingkatkan/diturunkan sebesar 1 satuan, maka nilai Keputusan Konsumen (Y) akan meningkat/menurun pula sebesar 1,240 satuan, dengan asumsi variabel independen lain konstant. Dengan demikian, apabila harga diturunkan maka konsumen mahasiswa akan meningkatkan transaksi pembelianya. Begitu pula sebaliknya, jika harga cenderung meningkat, maka konsumen akan mengurangi permintaanya.

Pelayanan berpengaruh positif dan signifikan terhadap keputusan pembelian konsumen mahasiswa fakultas ekonomi dan Bisnis Islam IAIN Sultan Amai Gorontalo untuk melakukan transaksi pembelian secara online. Pada penelitian ini diperoleh nilai estimasi koefisien regresi variable Pelayanan $\left(\mathrm{X}_{2}\right)$ sebesar 0,356. Nilai ini berarti, jika Pelayanan $\left(\mathrm{X}_{2}\right)$ ditingkatkan/diturunkan sebesar 1 satuan, maka nilai indeks harga saham (Y) akan meningkat/menurun pula sebesar 0,356 poin, dengan asumsi variabel independen lain konstant. Dengan demikian, apabila kualitas layanan pada sistem jual beli online ditingkatkan, maka akan diikuti pula oleh minat konsumen untuk melakukan transaksi pembelian. Begitu pula sebaliknya, jika kualitas layanan pada system jual beli online menurun, maka akan menurun pula minat konsumen untuk melakukan transaksi. Secara bersama-sama, harga dan layanan transaksi online berpengaruh signifikan terhadap keputusan pembelian konsumen mahasiswa Fakultas Ekonomi dan Bisnis Islam IAIN Sultan Amai Gorontalo. 


\section{DAFTAR PUSTAKA}

Amrullah, Siburian Pamasang S., Zainurossalamia Saida, Pengaruh Kualitas Produk dan Kualitas Layanan terhadap Keputusan Pembelian Konsumen Motor Honda. Jurnal Ekonomi dan Manajemen, Vol. 113, (2), 2016. ISSN print: 1907-3011, ISSN online: 2528-1127.

Arifin, Penelitian Pendidikan. Pendekatan kuantitatif dan Kualitatif, Yogyakarta: Lilin Persada Press, 2010.

http://hasanismail25.wordpress.com/2013/05/15/bab-5-dan-6-defenisi-dan-dasar-dasarpengambilan-keputusan/. Diakses tanggal, 25/06/19.

Kotler P., Armstrong,. Principles of Marketing, New Jersey: Prentice-hall, inc. Edisi 13, 2010.

Kotler Philip, Gary, Amstrong. Princip-Princip Pemasaran. Penerjemah Imam Nurmawan, Jakarta: Salemba 4, 2001.

Philip Kotler dan Amstrong dalam Nembah. Prinsip-Prinsip Pemasaran, Jakarta: Erlangga Jilid Satu, Edisi Keduabelas, 2008.

Setiawati Elis dan Tysa Prasetyoning Winandi Anggraini Ari. Kajian Multi Disiplin untuk Mewujudkan Poros Maritim dalam Pembangunan Ekonomi Berbasis Kesejahteraan Rakyat. Prosiding Seminar Nasional Multi Disiplin Ilmu dan Call For Papers UNISBANK (SENDI_U). 2018.

Tjiptono Fandy. Service Management Mewujudkan Layanan Prima, Yogyakarta: Andi Offset, Edisi 2, 2008.

Tjiptono, F. Candra G. Service and Quality satisfaction, Yogyakarta: Andi Offset, 2005.

Tjiptono, F., \& Chandra G. Service Quality, Satisfaction, Yogyakarta: Andi Offset, 2007

Tripjono Fandy,. Prinsip-Prinsip Total Quality Service, Yogyakarta: Andi, 2004.

Tripjono Fandy. Strategi Pemasaran, Yogyakarta: Andi, Edisi 4, 2015.

Widyawati Dwi, Pengaruh Kualitas Produk dan Harga terhadap Keputusan Pembelian Produk

Tupperware di Yogyakarta. Jurnal Manajemen, Vol. 2 No. 2, 2012.

William G. Zigmund,. Business Research Methods, Publisher: McGraw, Edition 8, 1994.

Zeithaml, V.A., Biner, M. J. dan Gremler, D. Service Marketing-Integrating Customer, Focus Across the Firm, New York: McGraw-Hill. 2009. 